\title{
Bullying in Students with and Without Special Educational Needs
}

\author{
Vasiliki Kaminaridi (Corresponding Author) \\ Philologist, MA Special Education Teacher \\ European University of Cyprus, Cyprus \\ E-mail: vkaminaridi@gmail.com
}

Evanthia Tsaliki

Scientific Collaborator, Department of Sciences of Education

European University of Cyprus, Cyprus

E-mail: inka140@hotmail.com

Received: October 17, 2017 Accepted: November 7, 2017 Published: December 5, 2017

doi:10.5296/gjes.v3i2.12244 URL: https://doi.org/10.5296/gjes.v3i2.12244

\begin{abstract}
In the present study a concise presentation of the phenomenon of school bullying in students with and without special educational needs is attempted. Initially, a distinction is made between the terms "violence" and "school bullying", the second term being a sub-category of the broader concept of violence. Then, some of the most important definitions which have been attributed to "school bullying" are presented. It is noted that there is no universally accepted definition, as the definition of such a complex and multidimensional phenomenon is not an easy task. Then, the main forms of school bullying are described as well as its principal causes are presented. Finally, international and national research data - principally from Greece - on the frequency of school bullying based on the type of disability/special educational needs is presented while suggestions are made for its confrontation.
\end{abstract}

Keywords: School bullying, Students with special educational needs, Violence, Types, Causes, Frequency 


\section{Introduction}

In recent years there has been an increase in research interest in bullying both at international and national level (Greene, 2006). According to Rigby (2008), the particular research attention that has been given to the study of the phenomenon in recent decades is due to the fact that in many countries the basic rights of people who are subject to discrimination and ill-treatment are recognized as belonging to specific categories (gender, nationality, physical or mental disability).

In terms of the school context, the explosion of interest observed over the last few decades on the phenomenon (Cook, Williams, Guerra, Kim, \& Sadek, 2010; Stefanakou, Tsiantis, \& Tsiantis, 2014) could be attributed on the one hand to the empirical findings that demonstrate that it occurs at all levels of education and, on the other hand, to the significant consequences that the experience of intimidation might have on the victim, the perpetrator, but also the whole school class and unit (Debardieux \& Errard, 2011).

Despite the large number of research studies conducted so far in the Greek as well as in the international context regarding the phenomenon of school bullying, the intimidation of pupils at school is a relatively new area of research.

In addition, the fact that acts of intimidation are directly linked to high levels of insecurity in school and generally to negative mental effects in a micro and macro horizon, make the phenomenon of a particular research interest.

Considering all of the above, this research aims to provide school community with a comprehensive review that documents our current understanding of the complexity of bullying among school-aged youth as well as directions for future research and intervention efforts.

\section{Violence and School Bullying}

Inherent in human nature, violence and aggression have always occupied research at an interdisciplinary level. On the contrary, school bullying has been recorded in scientific terminology quite recently, since the first attempts for a systematic study of the phenomenon were initiated by the Norwegian Professor Dan Olweus in the 1970s. Over the past twenty years - and especially after the international debate on bullying - school bullying has also become a major concern for the Greek scientific community (Kourkoutas, 2012; Psalti, 2012).

Nevertheless, it is a fact that nowadays there is confusion in the use of terms violence and intimidation when they refer to school environment. At this point, it should be made clear that school bullying is not an identical concept of violence or aggression, as any aggression at school is not intimidating (Harachi, Catalano, \& Hawkins, 1999). We would probably say that this is a sub-category of the wider concept of violence (Roland \& Idsoe, 2001).

\section{Definition of School Bullying}

As mentioned above, Dan Olweus initiated the world's first systematic bullying research. 
According to Olweus (2009), "a student is being bullied or victimized when he or she is exposed, repeatedly and over time, to negative actions on the part of one or more other students". Thus bullying is characterized by the following three criteria: (a) it is an aggressive behavior or intentional "harmdoing" (b) which is carried out "repeatedly and over time" and (c) in an interpersonal relationship characterized by an imbalance of power. One might add that the bullying behavior often occurs without apparent provocation.

Olweus (2007) also marks the difference between bullying and "teasing" in the game. "Teasing" usually happens between friends and does not involve the induction of bodily pain to others. On the contrary, school bullying involves people who are not friends. The characteristic imbalance of power lies in the fact that a child happens to be bigger or more popular or even in the fact that some children can conspire against someone else. "Teasing" can easily be turned into bullying if the child feels that the actions of others are not within the limits of the game and, most importantly, if they happen for a very long time (Smith \& Shu, 2000).

Another definition of school bullying, which is widely accepted, is that of Tattum and Tattum (1992), which states that "bullying is the willful, conscious desire to hurt another and put him/her under stress". We note that in this definition there is premeditated conduct from the part of the perpetrator. He is aware of the evil he is going to cause, and that may well please him (Rigby, 2001).

A similar perception of the perpetrator's way of thinking is also provided by the definition of the Scottish Council for Research in Education, which states that school bullying is the deliberate and conscious wish of the offender to harm, threaten or intimidate someone (Johnstone, Munn, \& Edwards, 1991).

As it is understood, there is no universal definition of school bullying with which all researchers agree, since each of them focuses on different aspects of the phenomenon. The difficulty of finding a universally accepted definition of school bullying is justified, as the definition of such a complex and multidimensional phenomenon is not an easy task.

Despite the fact that there is no single definition of the phenomenon, we observe that there are some criteria that are embedded in these definitions and constitute school bullying differentiating it from other forms of violence manifested in the school. These criteria are:

- the perpetrator's intention

- the infliction of pain on the victim

- the repeatability and duration of intimidating behavior

- the imbalance of power

- the unprovoked aggressive behavior of the offender

\section{Types of School Bullying}

School bullying may take various forms. It is categorized according to the ways it occurs and 


\section{Macrothink}

it depends on the means used by the offender.

Thus, we observe the following forms:

\section{- Verbal bullying}

It is the most common form of school bullying. Chirping, insults, quarrels, as well as sarcasm, contempt, irony and false propaganda are some of the most well-known forms of this kind of intimidation. Verbal intimidation often undermines the child's self-confidence (Bright, 2005).

\section{- Physical bullying}

It is an equally frequent form of school bullying, which involves a wide range of actions such as blows, kicks, jerks, slaps, strokes, hair pulls, harnessing and / or damage to personal property (Kim, Koh, \& Leventhal, 2005).

\section{- Indirect, social, relational bullying}

This type of bullying includes behaviors such as non-acceptance and exclusion of the victim from social groups or activities and dissemination of rumors. In indirect intimidation, the target of the perpetrators is to shake the victim's self-esteem. To achieve this goal, they use tactics such as isolation, gestures, nods and generally hostile non-verbal communication. For this reason, indirect intimidation is considered to be the hardest-to-detect form of emotional abuse as opposed to direct intimidation, which is characterized by "relatively visible attacks on the victim" (Rigby, 2008).

\section{- Cyber bullying}

This form of school bullying involves the use of electronic media (mobile phones, emails, chat rooms and other social media) for the public humiliation of the victim (Dracic, 2009).

\section{- Sexual Bullying}

This type of school bullying includes immoral gestures, dissemination of rumors about the sexuality and sexual experiences of the victim, threats, insulting messages, physical contact without the consent of the victim, sexual attacks (Linden, 2009). Sexual intimidation should not be confused with sexual harassment (Rigby, 2008).

\section{- Racial bullying}

Racial bullying is the negative treatment of a person belonging to a different racial/ethnic/religious/social/economic group than that of the offender (Rigby, 2001). This type of bullying maximizes and strengthens the victim's pre-existing experiences, which are associated with feelings of frustration and deprivation (Smith, 2003).

At this point, it is worth noting that forms of school bullying appear sometimes in isolation, sometimes in combination and vary in intensity. Finally, these behaviors are manifested by either an individual or a group of individuals. 


\section{The Causes of School Bullying}

There are many interpretations about the phenomenon of school bullying. Some of them attribute intimidation to biological factors and others to elements of the personality of children in relation to the social and environmental conditions that prevail ( $\mathrm{Li}, 2008)$. The description of the traits of the child-offender and the child-victim plays a decisive role in assessing the extent of the phenomenon.

\subsection{Bully and Victim Characteristics}

\subsubsection{Characteristics of Bullies}

The perpetrators of intimidating behavior are often presented as aggressive, impulsive, lacking self-control and having positive attitude towards violence (Espelage \& Swearer, 2003). Many researchers, psychologists and psychiatrists argue that the psychological profile of the victims is outlined as insecurity, low self-esteem, and general feelings of inadequacy (Rigby, 2004; Lee, 2006). Olweus does not endorse this view. On the contrary, based on the findings of his research, he suggests that perpetrators are close to the average regarding anxiety and self-esteem level. In general, the relationship between intimidating behavior and self-esteem is controversial (O’Moore, 2000).

The social skills of bullies are highly developed (Morrison, 2007). Nevertheless, it has been argued that the perpetrators have limited social and interpersonal skills (Andreou \& Metallidou, 2004). It should also be noted that regardless of the degree of social skills they possess, they deprive or have developed to very low degree empathy at both cognitive and emotional level. In other words, they face difficulties in understanding the thoughts and feelings of their victims (Olweus, 2009).

\subsubsection{Characteristics of Victims}

According to Olweus (2009), typical victims are more vulnerable and insecure than average students. Their self-esteem is low and therefore they have a negative image for themselves (McLaughlin, Byers, \& Vaughn, 2010). They are also quite sensitive and shy.

Children-victims find it difficult to create friendships due to their shyness and lack of social skills (Lee, 2006). According to Hodges and Perry (1999), the lack of friendship is one of the most important risk factors for victimization. It is therefore obvious that the development of social skills as well as the presence of one or more friends in the child's life may limit the negative effects of victimization and act as a shield against it (Ellis \& Zarbatany, 2007). As far as their physical appearance is concerned, victims are usually small or have a characteristic that distinguish them from other children, such as obesity, acne, some peculiarity - disability, sexual orientation etc. (Smokowski \& Kopasz, 2005).

The characteristics mentioned above refer to the so-called "passive victims". However, Olweus separates passive victims from another category of victims, the so-called "provocative victims". These children have nervous and aggressive behavior, they present attention problems and often cause tension and nervousness in their environment with their behavior. They are also constantly striving to demonstrate, display and monopolize the 
attention of others, as well as seeking competitive and conflicting situations with masochistic insistence (Olweus, 1993).

\subsection{The Role of the Family}

In addition to the individual characteristics of the offender and the victim, the family plays a key role in promoting a child's aggressive attitude and, in particular, the quality of inter-familial relationships (Olweus, 2009).

Olweus (2009) mentions three factors that play an important role in the development of aggressive behavior. Firstly, the emotional attitude of the parents during the first years of the child's life, is particularly important. A negative attitude from the part of the parents, characterized by a lack of tenderness and involvement, may lead the child to manifest aggressive behavior against others (Suckling \& Temple, 2001).

The second determining factor is the level of tolerance that parents show against the aggressive behavior of their child. If parents do not set clear limits on the child's aggressive attitude, then the child is likely to develop aggressive behavior.

The third factor is the inappropriate upbringing methods adopted by parents. These methods may include corporal punishment, but also violent sympathetic outbursts. Children who are raised in a violent environment will also develop the same aggressive ways of behaving and claiming things. In general, it has been found that children who are exposed at domestic violence are very likely to intimidate their classmates (Baxendale, Cross, \& Johnston, 2012).

The structure and organization of the family (limits, rules, emotional climate), parents' pedagogical attitudes, the quality and type of disciplinary measures, and the relationship of parents with their children are considered to be highly relevant to the development of aggressive behaviors and the creation of interpersonal emotional and cognitive schemes that enhance aggressive behaviors (Pepler \& Craig, 2000).

\subsection{Teachers' Responsibility}

Apart from family, educators play an important role in the appearance of the phenomenon of school bullying. More specifically, surveys have shown that inadequate teacher training about tackling school bullying effectively is an important factor in enhancing victimization (Mishna, Scarcello, Pepler, \& Wiener, 2005; Beran, 2006). It is therefore necessary to provide more advanced training, including various methods of intervention and knowledge of the appropriate selection and implementation of such interventions (Troop - Gordon \& Ladd, 2015).

The emphasis laid by teachers on the sterile transmission of knowledge plays a key role in the emergence of intimidating behavior, thus excluding pupils' education. However, it should be stressed here that the transfer of knowledge is not the sole purpose of the teacher but, in addition, the teacher is required to cultivate moral principles, create motivation for progress, and prepare students to join the community. 


\subsection{Poor Economic Conditions}

Research suggests that the socio-economic level of the community plays a determining role in the occurrence of school bullying incidents. In particular, according to a study conducted in schools in Sheffield, England, involvement in bullying incidents, either in the role of the perpetrator or that of the victim, was statistically more likely for students who attended schools in economically deprived areas (Whitney \& Smith, 1993).

In Scotland, Mellor (1999) showed that children whose parents held bureaucratic and managerial positions were more likely to be intimidated, while children whose parents were laborers were more likely to be victims and perpetrators. According to another survey conducted in Netherlands, intimidation is more common in children of socially degraded areas or ghettos in the city center (Junger - Tas \& van Kesteren, 1999).

Contrary to the above, Olweus (1999) claimed that in Sweden intimidation was not related to boys' social class. Researchers from Spain and France reached the same conclusion. (Almeida, 1999; Ortega \& Mora - Merchan, 1999). Similarly, in France, a study of the relationship between the bullying behavior of 77 pupils and their parents' social class revealed that there was no statistically significant relationship (Duyme, 1990).

It appears here that the studies on the relationship between children's involvement in bullying and the social class of their parents give mixed results, since in some surveys the incidence of intimidating behavior is positively correlated with the socio-economic level of the family (Rigby \& Bagshaw, 2001; Tippett \& Wolke, 2014), while in other studies there is no such relationship (Almeida, 1999; Olweus, 1999).

\subsection{The Role of Mass Media, the Internet and Electronic Games in Developing Bullying} Behaviors

One of the major causes of the phenomenon of school bullying is the often-over projected violent images from the mass media and the internet, as well as video games (or other types of computer games) that promote the attack model hero, who, through the use of force, is acclaimed in his social environment. The constant projection of scenes of violence and negative social models from television and electronic games pushes children into gradual adoption and imitation of similar behaviors and attitudes.

\section{Research on Bullying of Children with Disabilities/Special Educational Needs}

Despite the widespread diffusion of school bullying in educational research, there is less research on the relationship between school bullying and pupils with special educational needs (SEN). In these surveys, it appears that students with SEN are at a higher risk of being victimized than their typically developing peers. Indeed, existing epidemiological data in North America show that a child with special needs (cognitive, physical, developmental, behavioral dysfunctions) is 3.44 times more likely to undergo some form of milder or more serious ill treatment than other children. Rose, Monda-Amaya, and Espelage (2011) reported that $20-30 \%$ of the student population has been involved in school bullying as victims, while in students with disabilities this figure reaches $50 \%$. This is because students with SEN have 
deficits or lag behind factors that protect them against the risk of school bullying, such as self-esteem, social skills, self-confidence, positive self-image, and friendly relationships.

On the other hand, according to a survey, the percentage of children with SEN who suffer intimidation is lower than that of typically developing students (Woods \& Wolke, 2004). It appears at this point that the findings do not provide a clear picture of the problem, since in some surveys the disability does not seem to affect pupils' participation in school bullying situations, while in other surveys the percentage of children with disabilities involved in school bullying is much higher than that of typically developing children.

With regard to the role of pupils with SEN in bullying incidents, most research findings have shown that these students are more often in the role of the victim (Carlson, Flannery, \& Kral, 2005; Singer, 2005; Luciano \& Savage, 2007), while fewer are the research data presenting these students in the role of the perpetrator (Casey, Levy, Brown, \& Brooks-Gunn, 1992; Nabuzoka, 2000). It is worth noting, however, that there are also surveys presenting students with SEN in the role of the perpetrator and the victim at the same time (Kaukiainen et al., 2002; Kokkinos \& Antoniadou, 2013). In this case, the researchers suggest that this behavior is learned and is probably a reaction to a constant past victimization or to a generalized lack of social skills (Rose, Monda - Amaya, \& Espelage, 2010).

As far as the most prevalent forms of intimidation are concerned, existing research data show that pupils with SEN suffer direct and indirect forms of intimidation (verbal, physical and psychological) with the same frequency (Kokkinos \& Antoniadou, 2013). On the other hand, when these students are in the role of the perpetrator, they seem to prefer direct forms of intimidation, such as blows or verbal attacks, to indirect forms such as social exclusion or dissemination of false rumors at the expense of the victim, since the latter require complex cognitive and social skills, that students with SEN don't possess (Kaukiainen et al., 2002).

\section{Frequency of School Bullying Based on the Type of Disability/Special Educational Needs}

Various scientific publications recognize the existence of special groups with special educational needs that are vulnerable to school bullying, such as children with learning difficulties, children with attention deficit hyperactivity disorder (ADHD), pervasive developmental disorders (PDD), physical disabilities, health problems and speech problems (Carlson et al., 2005; Flynt \& Morton, 2007).

\subsection{Intellectual Disability (Mental Retardation)}

According to researchers, children with mental retardation are more likely to become targets of intimidating behaviors than those with less observable forms of disability or typically developing students (Sheard, Clegg, Standen, \& Cromdy, 2001). However, Monchy, Pijl, and Zandberg (2004) report that mentally retarded pupils are less often victimized than pupils with less visible forms of disability.

In addition, research by Reiter and Lapidot - Lefler (2007) showed that the victimization of pupils with mental retardation occurs at the same frequency in both inclusive and special 
educational contexts. This finding is in contradiction with other surveys which state that the rates of victimization of students with mental retardation are 2 to 3.5 times higher in special schools than in inclusive ones (Martlew \& Hodson, 1991; Morrisson, Furlong, \& Smith, 1994).

Finally, according to the literature, the most frequent forms of intimidation suffered by students with mental retardation are insults and physical violence (Andreou, Didaskalou, \& Vlachou, 2013).

\subsection{Autism / Asperger Syndrome}

Numerous scientific studies have shown that children with autism / Asperger syndrome are at a higher risk of becoming bullied than their typically developing peers (Little, 2002; Reid \& Batten, 2006; Montes \& Halterman, 2007). The high incidence of these students' victimization is due to their unclear articulation as well as to the "strange" movements and behaviors they manifest. Additionally, according to empirical data, children with developmental disorders (autism, Asperger syndrome) have higher rates of rejection than their peers and a higher incidence of verbal and physical attacks due to difficulties in social interaction and inability to perceive social standards (Crosse, Elyse, \& Ratnofsky, 1993).

Children with Asperger Syndrome are the most frequent victims (higher risk groups for intimidation and victimization) because they are unable to manage social skills, have a lack of cognitive skills and a failure to develop and maintain friendships.

\subsection{Attention Deficit Hyperactivity Disorder (ADHD)}

According to scientific research data, students with attention deficit hyperactivity disorder are at increased risk of being involved in school bullying, either as perpetrators or victims (Chamberlain, 2003). It seems that these students are often the targets of intimidating behaviors due to their low self-control and the inconvenience they inadvertently cause. Poor social skills or inappropriate behavior of some students with ADHD could elicit aggressive ways of responding by their peers. The most common forms of intimidating behaviors experienced by students with ADHD are verbal and social (Hoza, 2007).

\subsection{Mobility Problems}

Based on research data, it appears that students with kinetic problems are less likely to be bullied than typically developing students. This is because the peers of people with mobility problems understand the difference in strength and support them. On the other hand, there are studies that claim that students with kinetic disabilities are at greater risk of intimidation compared to their typically developing peers (Davis, Howell, \& Cooke, 2002; Pivik, McComas, \& Laflamme, 2002).

Additionally, Llewellyn (2000) reports that students with kinetic problems are more likely to be intimidated compared to students with a less apparent form of disability. The most common forms of intimidation experienced by these students are verbal (Dawkins, 1996), physical (Saylor \& Leach, 2009) and social (Llewellyn, 2000). 


\subsection{Learning Difficulties}

Various scientific publications have shown that students with learning difficulties are at a higher risk of being involved in school bullying, either as offenders or as victims, compared to their typically developing classmates (Norwich \& Kelly, 2004; Luciano \& Savage, 2007; Raskauskas \& Modell, 2011). Intimidation of students with learning difficulties is due to their reduced communication skills and low self-confidence. In addition, according to surveys, verbal abuse and direct physical violence are the most common types of intimidating behavior experienced by students with learning disabilities (Hellendoorn \& Ruijssenaars, 2000; Singer, 2005).

\section{Conclusions and Recommendations}

Summarizing the research data on school bullying, it is clear that school victimization is a major problem both in Greece and abroad in recent years. It is also noted that children with special educational needs are at higher risk of victimization than their typically developing peers, although there is research evidence supporting the opposite. Still, it has been found that the victimization suffered by pupils with SEN is primarily related to their disability. It follows from the above that the need for prevention and early intervention in children with SEN in the school context is imperative.

Then, some suggestions that could be the basis for designing curriculum programs to prevent and address school bullying in pupils with SEN are briefly presented. Since the teacher is the person who is in constant contact with the pupils and her / his behavior or managerial skills are vital to reinforce or prevent the emergence of aggressive behavior, it is necessary to train them on issues of crisis management, prevention and counteraction of intimidating behavior in a continuous and systematic way.

It is also necessary that school and family cooperate in order to prevent and tackle the problem of school bullying. In this context, frequent informative meetings of teachers, parents, school counselors, psychologists, social workers, etc. is suggested in order to organize common activities with a variety of themes, such as the phenomenon of school bullying. It is also important to raise the awareness of the entire educational and school community about school violence and short-term and long-term consequences it may have for the entire student population, in order to create a safe and accessible environment for all children. In the words of French ethnologist Françoise Héritier, "evil begins with indifference and resignation".

\section{References}

Almeida, A. (1999). "Portugal". In P. Smith, Y. Morita, J. JungerTas, D. Olweus, R. Catalano, $\&$ P. Slee (Eds.), The nature of school bullying: A cross-national perspective (pp. 174-186). London: Routledge.

Andreou, E., \& Metallidou, P. (2004). The relationship of academic and social cognition to behavior in bullying situations among Greek primary school children. Educational Psychology, 24, 27-41. http://dx.doi.org/10.1080/0144341032000146421 
Andreou, E., Didaskalou, E., \& Vlachou, A. (2013). Bully/victim problems among Greek pupils with special educational needs: Associations with loneliness and self-efficacy for peer interactions. Journal of Research in Special Educational Needs. http://doi.org/10.1111/1471-3802.12028.

Baxendale, S., Cross, D., \& Johnston, R. (2012). A review of the evidence on the relationship between gender and adolescents' involvement in violent behavior. Aggression and Violent Behavior, 17, 297-310. http://dx.doi.org/10.1016/j.avb.2012.03.002

Beran, T. (2006). A construct validity study of bullying. Alberta Journal of Educational Research, 52(4), 238-247.

Bright, R. (2005). It's just a grade 8 girl thing: Aggression in teenage girls. Gender and Education, 17(1), 93-101. http://dx.doi.org/10.1080/0954025042000301320

Carlson, E., Flannery, M., \& Kral, M. (2005). Differences in bully/victim problems between early adolescents with learning disabilities and their non-disabled peers. Retrieved 26-09-2017 from http://files.eric.ed.gov/fulltext/ED490374.pdf

Casey, R., Levy, S., Brown, K., \& Brooks-Gunn, J. (1992). Impaired emotional health in children with mild reading disability. Developmental and Behavioral Pediatrics, 13, 256-260. https://doi.org/10.1097/00004703-199208000-00003

Chamberlain, S. (2003). An interview with Susan Limber and Sylvia Cedillo: Responding to bullying. Intervention in School and Clinic, 38(4), 236. https://dx.doi.org/10.1177/105345120303800406

Cook, C., Williams, K., Guerra, N, Kim, T., \& Sadek, S. (2010). Predictors of bullying and victimization in childhood and adolescence: A meta-analytic investigation. School Psychology Quarterly, 25(2), 65-83. http://dx.doi.org/10.1037/a0020149

Crosse, S., Elyse, K., \& Ratnofsky, A. (1993). A Report on the Maltreatment of Children with Disabilities. Washington, DC: National Center on Child Abuse and Neglect, U.S. Department of Health and Human Services.

Davis, S., Howell, P., \& Cooke, F. (2002). Sociodynamic relationships between children who stutter and their non-stuttering classmates. Journal of Child Psychology and Psychiatry, 43, 939-947. https://doi.org/10.1111/1469-7610.00093

Dawkins, J. (1996). Bullying, physical disability and the pediatric patient. Developmental $\begin{array}{llll}\text { Medicine } \quad \text { Chd Neurology, 603-612. } & \end{array}$ https://doi.org/10.1111/j.1469-8749.1996.tb12125.x

Debardieux, E., \& Errard, L. (2011). Pour une meilleure connaissance de la violence en milieu scolaire: L'enquête de victimation en milieu scolaire. Cahiers de la Securite, 16, 22-28.

Dracic, S. (2009). Bullying and peer victimization. Materia Socio Medica, 21(4), 216-218.

Duyme, M. (1990). Antisocial behavior and postnatal environment: A French adoption study. 
The Journal of Child Psychology and Psychiatry and Allied Disciplines, 31(5), 699-710. https://doi.org/10.1111/j.1469-7610.1990.tb00811.x

Ellis, W., \& Zarbatany, L. (2007). Explaining friendship formation and friendship stability: The role of children's and friends' aggression and victimization. Merrill Palmer Quarterly, 53, 79-104. https://doi.org/10.1353/mpq.2007.0001

Espelage, D., \& Swearer, S. (2003). Research on school bullying and victimization: What have we learned and where do we go from here? School Psychology Review, 32, 365-383.

Flynt, S., \& Morton, R. (2004). Bullying and children with disabilities. Journal of Instructional Psychology, 31, 330-333.

Greene, M. (2006). Bullying in schools: A plea for a measure of human rights. Journal of Social Issues, 62(1), 63-79. https://doi.org/10.1111/j.1540-4560.2006.00439.x

Harachi, T., Catalano, R., \& Hawkins, J. (1999). "Canada”. In P. Smith, Y. Morita, J. Junger-Tas, D. Olweus, R. Catalano, \& P. Slee (Eds.), The nature of school bullying: A cross-national perspective (pp. 296-306). London: Routledge.

Hellendoorn, J., \& Ruijssenaars, A. (2000). Personal experiences and adjustment of Dutch adults with dyslexia. Remedial and Special Education, 21, 227-239. https://doi.org/10.1177/074193250002100405

Hodges, E., \& Perry, D. (1999). Personal and interpersonal antecedents and consequences of victimization by peers. Journal of Personality Social Psychology, 76, 677-685. http://dx.doi.org/10.1037/0022-3514.76.4.677

Hoza, B. (2007). Peer functioning in children with ADHD. Journal of Pediatric Psychology, 32, 655-663. https://doi.org/10.1093/jpepsy/jsm024

Johnstone, M., Munn, P., \& Edwards, L. (1992). Action against Bullying: A Support Pack for Schools. Edinburgh: Scottish Council for Research in Education.

Junger-Tas, J., \& van Kesteren, J. (1999). Bullying and Delinquency in a Dutch School Population. The Hague: Kugler Publications.

Kaukiainen, A., Salmivalli, C., Lagerspetz, K., Tamminen, M., Vauras, M., Mäki, H., \& Poskiparta, E. (2002). Learning difficulties, social intelligence, and self-concept: Connections to bully-victim problems. Scandinavian Journal of Psychology, 43, 269-278. https://doi.org/10.1111/1467-9450.00295

Kim, Y., Koh, Y., \& Leventhal, B. (2005). School bullying and suicidal risk in Korean middle school students. Pediatrics, 115(2), 357-363. https://doi.org/10.1542/peds.2004-0902

Kokkinos, C., \& Antoniadou, N. (2013). Bullying and victimization experiences in elementary school students nominated by their teachers for specific learning disabilities. School Psychology International, 34, 674-690. http://dx.doi.org/10.1177/0143034313479712

Kourkoutas, E. (2012). Children with Behavioral Problems: Ecosystemic Psychodynamic 
Interventions within Family and School Context. New York, Nova Science.

Lee, C. (2006). Exploring teacher's definitions of bullying. Emotional and Behavioral Difficulties, 11(1), 61-75. http://dx.doi.org/10.1080/13632750500393342

Li, Q. (2008). Bullying, school violence and more: A research model. International Electronic Journal for Leadership in Learning, 12(19). Retrieved from http://iejll.journalhosting.ucalgary.ca/iejll/index.php/ijll/article/view/562/224

Linden, M. (2009). Sexual bullying: thousands of pupils suspended. Retrieved May 7, 2016 from

http://www.independent.co.uk/.../sexual-bullying-thousands-of-pupils-suspended-1226341.ht $\mathrm{ml}$

Olweus, D. (2007). The Olweus Bullying Questionnaire. Center City, MN, Hazelden.

Little, L. (2002). Middle-class mothers' perceptions of peer and sibling victimization among children with Asperger's Syndrome and nonverbal learning disorders. Issues in $\begin{array}{llll}\text { Comprehensive } \quad \text { Pediatric } & \text { Nursing, } & \text { 25, }\end{array}$ http://dx.doi.org/10.1080/014608602753504847

Llewellyn, A. (2000). Perceptions of mainstreaming: A systems approach. Developmental Medicine and Child Neurology, 42, 106-115. http://dx.doi.org/10.1111/j.1469-8749.2000.tb00055.x

Luciano, S., \& Savage, R. (2007). Bullying risk in children with learning difficulties in inclusive settings. Canadian Journal of School Psychology, 22(1), 14-31. https://doi.org/10.1177/0829573507301039

Martlew, M., \& Hodson, J. (1991). Children with mild learning difficulties in an integrated and in a special school: Comparisons of behavior, teasing and teachers' attitudes. British $\begin{array}{llll}\text { Journal of } \quad \text { Educational } & \text { 355-372. }\end{array}$ https://doi.org/10.1111/j.2044-8279.1991.tb00992.x

McLaughlin, C., Byers, R., \& Vaughn, R. (2010). Responding to Bullying among Children with Special Educational Needs and/or Disabilities. London: Anti-Bullying Alliance. Retrieved from https://www.anti-bullyingalliance.org.uk/sites/default/files/uploads/SEND_bullying_Literatur e_Review.pdf

Mellor, A. (1999). “Scotland”. In P. Smith, Y. Morita, J. Junger-Tas, D. Olweus, R. Catalano, $\&$ P. Slee (Eds.), The nature of school bullying: A cross-national perspective (pp. 91-111). London: Routledge.

Mishna, F., Scarcello, I., Pepler, D., \& Wiener, J. (2005). Teachers' understanding of bullying. Canadian Journal of Education, 28, 718-738. https://doi.org/10.2307/4126452 
Monchy, M., Pijl, S., \& Zandberg, T. (2004). Discrepancies in judging social inclusion and bullying of pupils with behavior problems. European Journal of Special Needs Education, 19(3), 2004. http://dx.doi.org/10.1080/0885625042000262488

Montes, G., \& Halterman, J. (2007). Psychological functioning and coping among mothers of children with autism: A population-based study. Pediatrics, 119(5), 1040-1046. http://dx.doi.org/10.1542/peds.2006-2819

Morrison, B. (2007). Restoring Safe School Communities: A Whole School Response to Bullying, Violence and Alienation. Sydney: The Federation Press.

Morrison, G., Furlong, M., \& Smith, G. (1994). Factors associated with experience of school violence among general education, leadership class, opportunity class, and special day class pupils. Education and Treatment of Children, 17, 356-369. Retrieved from http://www.educationandtreatmentofchildren.net

Nabuzoka, D. (2000). Children with Learning Disabilities: Social Functioning and Adjustment. Leicester: BPS Blackwell.

Norwich, B., \& Kelly, N. (2004). Pupils' views on inclusion: Moderate learning difficulties and bullying in mainstream and special schools. British Educational Research Journal, 30(1), 43-65. http://dx.doi.org/10.1080/01411920310001629965

Olweus, D. (1993). Bullying at School: What We Know and What We Can Do. NY: Blackwell. http://dx.doi.org/10.1002/pits.10114

Olweus, D. (1999). "Norway". In P. Smith, Y. Morita, J. Junger-Tas, D. Olweus, R. Catalano, \& P. Slee (Eds.), The nature of school bullying: A cross-national perspective (pp. 7-27). London: Routledge.

Olweus, D. (2009). Understanding and researching bullying: Some critical issues. In S. Jimerson, S. Swearer, \& D. Espelage (Eds.), Handbook of bullying in schools: An inter-national perspective (pp. 9-33). New York: Routledge.

O’ Moore, M. (2000). Critical issues for teacher training to counter bullying and victimization in Ireland. Aggressive Behavior, 26(1), 99-111. http://dx.doi.org/10.1002/(SICI)1098-2337(2000)26:1<99::AID-AB8>3.0.CO;2-W

Ortega, R., \& Mora-Merchan, J. (1999). “Spain”. In P. Smith, Y. Morita, J. Junger-Tas, D. Olweus, R. Catalano, \& P. Slee (Eds.), The nature of school bullying: A cross-national perspective (pp. 157-173). London: Routledge .

Pepler, D., \& Craig, W. (2000). Making a difference in bullying. La Marsh Research Centre for Violence and Conflict Resolution, Research Report 60. Toronto, Ontario: York University. Retrieved from http://psycserver.psyc.queensu.ca/craigw/Craig_Pepler_2000_REPORT_Making_a_Differenc e_in_Bullying.pdf

Pivik, J., Mc Comas, J., \& Laflamme, M. (2002). Barrier and facilitators to inclusive 
education. Council for Exceptional Children, 69(1), 97-107. https://doi.org/10.1177/001440290206900107

Psalti, A. (2012). Bullies, victims, and bully- victims in greek schools: Research data and implications for practice. Hellenic Journal of Psychology, 9, 132-157.

Raskauskas, J., \& Modell, S. (2011). Modifying anti-bullying programs to include students with disabilities. TEACHING Exceptional Children, 44(1), 60-67. https://doi.org/10.1177/004005991104400107

Reid, B., \& Batten, A. (2006). B is for Bullied. London: National Autistic Society.

Reiter, S., \& Lapidot-Lefler, N. (2007). Bullying among special education students with intellectual disabilities: Differences in social adjustment and social skills. Intellectual and Developmental Disabilities, 45 , 174-181. https://doi.org/10.1352/1934-9556(2007)45[174:BASESW]2.0.CO;2

Rigby, K. (2001). Health consequences of bullying and its prevention in schools. In J. Juvonen, \& S. Graham (Eds.), Peer harassment in school: The plight of the vulnerable and victimized (pp. 310-331). New York: Guilford Press.

Rigby, K., \& Bagshaw, D. (2001). What hurts? The reported consequences of negative interactions with peers among Australian school children. Children Australia, 26(4), 36-41. https://doi.org/10.1017/S1035077200010464

Rigby, K. (2004). Addressing bullying in schools: Theoretical perspectives and their implications. School Psychology International, 25, 287-300. https://doi.org/10.1177/0143034304046902

Rigby, K. (2008). Children and Bullying: How Parents and Educators Can Reduce Bullying at School. Victoria: Blackwell Publishing.

Roland, E., \& Idsøe, T. (2001). Aggression and bullying. Aggressive Behavior, 27, 446-462. https://dx.doi.org/10.1002/ab.1029

Rose, C., Monda-Amaya, L., \& Espelage, D. (2011). Bullying perpetration and victimization in special education: A review of the literature. Remedial and Special Education, 32, 114-130. https://dx.doi.org/10.1177/0741932510361247

Saylor, C., \& Leach, J. (2009). Perceived bullying and social support students accessing special inclusion programming. Journal of Developmental and Physical Disabilities, 21, 69-80. https://doi.org/10.1007/s10882-008-9126-4

Sheard, C., Clegg, J., Standen, P., \& Cromby, J. (2001). Bullying and people with severe intellectual disability. Journal of Intellectual Disability Research, 45(5), 407-415. https://doi.org/10.1046/j.1365-2788.2001.00349.x

Singer, E. (2005). The strategies adopted by Dutch children with dyslexia to maintain their self-esteem when teased at school. Journal of Learning Disabilities, 38(5), 411-423. https://doi.org/10.1177/00222194050380050401 


\section{Macrothink}

Global Journal of Educational Studies

ISSN 2377-3936

2017, Vol. 3, No. 2

Smith, P., \& Shu, S. (2000). What good schools can do about bullying: Findings from a survey in English schools after a decade of research and action. Childhood, 7, 193-212. https://doi.org/10.1177/0907568200007002005

Smith, P. (2003). Violence in Schools: The Response in Europe. London, Routledge Falmer.

Smokowski, P., \& Kopasz, K. (2005). Bullying in school: An overview of types, effects, family characteristics and intervention strategies. Children \& Schools, 27(2), 101-110. https://doi.org/10.1093/cs/27.2.101

Stefanakou, A., Tsiantis, A., \& Tsiantis, J. (2014). A review of antibullying prevention and intervention programs in Greece. International Journal of Mental Health Promotion, 16, 19-27. http://dx.doi.org/10.1080/14623730.2013.857827

Suckling, A., \& Temple, C. (2001). Bullying: A Whole Approach. London: Jessica Kingsley Publishers.

Tattum, D., \& Tattum, E. (1992). Bullying: A whole-school response. In N. Jones, \& E. Jones (Eds.), Learning to behave: Curriculum and whole school management approaches to discipline (pp. 67-84). London: Kogan Page.

Tippett, N., \& Wolke, D. (2014). Socioeconomic status and bullying: A meta-analysis. American Journal of Public Health, 104, 48-59. http://doi.org/10.2105/AJPH.2014.301960

Troop-Gordon, W., \& Ladd, G. (2015). Teachers' victimization-related beliefs and strategies: Associations with pupils' aggressive behavior and peer victimization. Journal of Abnormal Child Psychology, 43, 45-60. http://doi.org/10.1007/s10802-013-9840-y

Whitney, I., \& Smith, P. (1993). A survey of the nature and extent of bully/victim problems in junior/middle and secondary schools. Educational Research, 35(1), 3-25. http://dx.doi.org/10.1080/0013188930350101

Woods, S., \& Wolke, D. (2004). Direct and relational bullying among primary school children and academic achievement. Journal of School Psychology, 42, 135-155. http://dx.doi.org/10.1016/j.jsp.2003.12.002

\section{Copyright Disclaimer}

Copyright for this article is retained by the author(s), with first publication rights granted to the journal.

This is an open-access article distributed under the terms and conditions of the Creative Commons Attribution license (http://creativecommons.org/licenses/by/3.0/). 